Article

\title{
Corporate Social Responsibility and Rule 144A Debt Offerings: Empirical Evidence
}

\author{
Wassim Dbouk ${ }^{1}$, Dawei Jin ${ }^{2, *}$, Haizhi Wang ${ }^{3}$ and Jianrong Wang ${ }^{3}$ \\ 1 Suliman S. Olayan School of Business, American University of Beirut, Beirut 1107 2020, Lebanon; \\ wd08@aub.edu.lb \\ 2 Information and Safety Engineering School, Zhongnan University of Economics and Law, 182 Nahu Ave, \\ East Lake High-Tech Development Zone, Wuhan 430073, China \\ 3 Stuart School of Business, Illinois Institute of Technology, 565 W Adams St, Chicago, IL 60661, USA; \\ hwang23@stuart.iit.edu (H.W.); jwang151@hawk.iit.edu (J.W.) \\ * Correspondence: jdw@zuel.edu.cn
}

Received: 28 September 2018; Accepted: 15 November 2018; Published: 20 November 2018

\begin{abstract}
Rule 144A allows a firm to issue securities without a public registration statement with the Securities and Exchange Commission, and only qualified institutional investors can purchase such securities. In this study, focusing on corporate bonds issued under Rule 144A, we empirically investigate the relationship between the corporate social responsibility (CSR) of issuing firms and the bond yield spread at issuance. We document a significant and positive relation between CSR concerns, whereas CSR strengths seem to play an insignificant role in determining bond yield spread. Our main findings are robust to the instrumental variable approach and simultaneous equation estimation to address the potential endogeneity issues. We further explore the time-series changes in issuing firms' CSR profiles, and report that institutional investors demand a higher bond yield spread when issuing firms' exposure to higher social, environmental, and stakeholder concerns. Our analyses reveal that the main sources of such risk exposure are stakeholder conflict and concerns from primary stakeholder groups.
\end{abstract}

Keywords: private placement; Rule 144A; bond yield spread; corporate social responsibility

JEL Classification: G28; G32; M14

\section{Introduction}

The Securities and Exchange Commission (SEC) has institutionalized regulation regarding security issuances under Rule 144A since 1990. Firms can privately place their securities under Rule 144A without filing a public registration statement, and only qualified institutional investors can purchase such securities (Arena 2011; Chaplinsky and Ramchand 2004). Although firms can issue both equity and debt under Rule 144A, the volume of debt issuance is nearly eight times the amount of equity raised (Chaplinsky and Ramchand 2004). Rule 144A allows for a fast issuing procedure with less information disclosure burden. Nonetheless, the lack of registration results in insufficient time for potential investors to conduct due diligence (Fenn 2000) to fully understand the issuing firms' financial conditions. As a result, investors purchasing privately placed securities may render themselves to exploitation by issuers because of increased asymmetric information. Therefore, in order to reach efficient contracts, investors may resort to other reference points to obtain extra information and assess the creditworthiness of issuing firms. Such information will then be factored into the price formation process of securities placed under Rule 144A.

Recent studies have stressed the prevalence of firms to engage in corporate social responsibility (CSR), because firms increasingly face demands from external stakeholders to address social and 
environmental issues. CSR activities help firms enhance their corporate social performance, and in turn improve their financial performance (Li et al. 2016; Hasan et al. 2018). More important, the existing literature has documented that CSR activities can effectively reduce firm risk and build social capital to facilitate efficient contracting with other economic agents in the capital market (Amiraslani et al. 2018; Orlitzky and Benjamin 2001). In parallel, for the last two decades, institutional investors have been involved in socially responsible investing in which the institutional investors screen firms based on desirable or undesirable characteristics in the profile of firm social performance (Chava 2014).

In this study, focusing on the bonds issued under Rule 144A by United States (U.S.) firms, we examine the relation between issuing firms' CSR profiles and the bond yield spread at issuance. Firm investments in CSR activities incur significant cost and divert scarce resources away from productive activities (Goss and Roberts 2011). The corporate decision-making process becomes more complicated than simply maximizing shareholder value (Amit and Wernerfelt 1990; Bettis 1983; Orlitzky and Benjamin 2001; Stulz 1996). As such, the information content in a particular firm's CSR profile is opaque and hard to evaluate. Investors purchasing securities under Rule 144A are typically sophisticated institutional investors with great experience and expertise assessing complicated financial claims. Therefore, the institutional features of Rule 144A debt offerings present an ideal context to investigate whether and to what extent sophisticated institutional investors extract information from issuing firms CSR profiles and incorporate that information in the bond contracting under Rule 144A.

One strand of research generally confirms that CSR involvement reduces firm risk in various contexts. For example, using different measures of CSR activities, researchers report that CSR involvement can effectively reduce the vulnerability of future cash flows, lower market-based risk (Albuquerque et al. 2014; Cai et al. 2016; Chang et al. 2014; Cheung 2016; Lee and Faff 2009; Godfrey et al. 2009; Harjoto and Jo 2015; Luo and Bhattacharya 2009), and induce safer profit-seeking incentives (Bae et al. 2011). Other empirical studies have shown that good CSR relationships are negatively correlated with firm credit risk and bankruptcy risk (Godfrey 2005; Hsu and Chen 2015; Kytle and Ruggie 2005), and they prevent firms from taking excessive risks (Harjoto and Laksmana 2016). Therefore, the risk mitigation view of CSR suggests that investors will demand a lower yield spread of privately placed bonds by firms with better corporate social performance.

Nonetheless, another line of research has posited that firm resources may be misallocated or appropriated (Becchetti et al. 2013; Garriga and Melé 2004; Margolis and Walsh 2003). In this sense, CSR activities are controversial mainly because of their voluntary nature beyond regulatory compliance (McWilliams and Siegel 2001). It is plausible that firm managers allocate resources to improve firm social conditions and stakeholder welfare, but not necessarily maximize shareholder value. Barnea and Rubin (2005) contended that firm management has the incentive to make excessive investments in CSR at the cost of shareholders and take the credit for CSR initiatives. Investment in CSR may negatively affect the productive operation and expose firms to higher credit risk. Therefore, firms overinvesting in CSR may have to pay a higher premium to raise external funds.

In the context of security issuance through private placement (i.e., Rule 144A), issuing firms tend to have low credit quality (Arena 2011), and are subject to significant information asymmetry (Chandra and Nayar 2008). Issuing firms' CSR profiles may provide additional information for institutional investors to assess their credit risk and determine the cost of capital (Cheng et al. 2014; El Ghoul et al. 2011; Oikonomou et al. 2014). Do investments in CSR activities really reduce firm risk, thus lead to a lower cost of financing? Does incompliance with regulations (Salama et al. 2011) and potential stakeholder conflicts (Becchetti et al. 2012) result in a higher credit risk? Investigating the relation between the CSR profiles of issuing firms and bond yield spread at issuance under Rule 144A can shed further light on this important research question, and further advance our understanding regarding the CSR policy and its relationship with firm financial decisions and outcomes.

In this study, we retrieve information on bonds issued under Rule 144A from the Thomson Reuters SDC Platinum New Issue Database (SDC) in the period from 1998 to 2013. We use information from the KLD Research \& Analytics database (KLD) to measure the corporate social performance of 
our sample-issuing firms. We document a significantly positive relation between the CSR concerns and bond yield spread at issuance under Rule 144A. In addition, CSR strengths seem to play an insignificant role in determining bond yield spread. Endogeneity issues arise because firms voluntarily engage in CSR-related activities, and the price term and non-price term in loan contracts can be simultaneously determined. Our results are robust to the instrument variable approach and simultaneous equation estimation to address the potential endogeneity issues.

We further investigate whether institutional investors extract information from the time-series changes of corporate social performance of issuing firms. We examine the changes in CSR strengths and concerns for three, four, and five-year windows before bond issuance. Our results indicate that indeed, investors incorporate the dynamic changes of CSR scores into the pricing of Rule 144A debt offerings. Specifically, the time-series changes of CSR concerns result in higher bond yield spread if such changes expose the issuing firms to higher environmental, social, and stakeholder risk. We also investigate the sources of the potential credit risk stemming from issuing firms' CSR concerns. We find that if an issuing firm's CSR policy is associated with more stakeholder conflicts, or higher concerns from primary stakeholders, institutional investors tend to demand higher bond yield spread.

We believe that our study contributes to the existing research in several ways. First, focusing on privately placed bonds, we establish a robust link between a firm's CSR profile and its cost of debt, and add to the literature (Chava 2014; El Ghoul et al. 2011; Goss and Roberts 2011) by providing additional and novel evidence that is consistent with externalities of socially irresponsible activities. Second, in a closely related research study by Amiraslani et al. (2018), they reported an insignificant relation between CSR and bond yield spread. We posit that the effect of social capital and trust generated from CSR involvement on the firm cost of capital is context-dependent. The complexity in CSR strategies makes it difficult to interpret the information content in CSR profiles, and sophisticated investors (e.g., banks and qualified institutional investors) are better equipped with the necessary expertise to do so. The investigation in the context of Rule 144A debt offerings manifests our conjecture. Third, we further show that institutional investors can extract information from both the cross-sectional variations and time-series changes of issuers' CSR profiles. Last, we show that institutional investors are more sensitive when CSR externalities lead to stakeholder conflicts and concerns from primary stakeholders.

The rest of our paper is organized as follows. Section 2 reviews the related literature, and Section 3 details the data, sample, and measures. In Section 4, we discuss our identification strategies and report empirical results. Section 5 summarizes and concludes.

\section{Related Literature}

In this study, we focus on debt offerings under Rule 144A, and highlight a few distinct features of Rule 144A debt offerings compared with public debt. Rule 144A is adopted in 1990 by the SEC to improve the liquidity of private placement of both equity and debt. Securities offered under Rule $144 \mathrm{~A}$ are not required to be registered with the SEC, and are not allowed to be traded among individual investors, but may be traded immediately among qualified institutional buyers. Domestic firms in the U.S. tend to sell securities that are eligible to be subsequently registered in a short period of time (Huang and Ramirez 2010). Rule 144A permits a minimum level of public-accessible information and a rapid issuance without registration with the SEC (Fenn 2000). When the Rule 144A debt is subsequently registered, the debt carries the nature of public market debt, and the investors enjoy the benefit of public market liquidity (Fenn 2000).

Institutional investors have limited legal protection in Rule 144A debt offerings, because they are typically sophisticated investors (Arena 2011). Institutional investors tend to demand a higher premium on the issued securities, and are likely to explore various sources of information, including issuing firms' CSR profiles to assess the riskiness of the issuances. A firm managing for stakeholders has to allocate resources to fulfill the demands of important stakeholders by engaging in various CSR activities (Harrison and Bosse 2013; McWilliams and Siegel 2001; Waddock and Graves 1997). 
Therefore, firms engaging in CSR activities are often confronted with the question of whether "doing good and doing well" converge (Peterson 2004). Numerous empirical studies have tried to confirm the existence of shareholder wealth creation through socially desirable decisions to legitimize CSR on a sound economic ground. However, research that examines the link between CSR and firm performance from the perspective of debt is scant. Given the distinct features of Rule 144A debt offerings, it is important to understand how investors make use of issuing firms' CSR profiles to extract information and incorporate their assessments to price the debt.

Three major views exist regarding the relation between CSR involvement and the cost of debt. For example, the risk mitigation view posits that a well-balanced CSR strategy can enhance firm performance and reduce potential risks, thus stabilizing income streams, as well as ensuring a firm's solvency. CSR strategy is widely adopted as a risk-management tool in corporate decisions (Benlemlih and Girerd-Potin 2017; Jo and Na 2012; Orlitzky and Benjamin 2001). The voluntary nature of CSR activities (Godfrey et al. 2009) can signal to important stakeholder groups that socially responsible firms are willing to act altruistically (Mackey et al. 2007). Consequently, CSR involvement can produce social capital that offers "insurance-like" protection (Godfrey et al. 2009; Lins et al. 2017; Minor and Morgan 2011) against adverse events, and even results in better firm performance. The existing literature provides evidence that the socially responsible firms are rewarded in financing by experiencing more favorable credit ratings, the ease of access to the finance, and a lower cost of equity and debt financing (Cheng et al. 2014; El Ghoul et al. 2011; Jiraporn et al. 2014). Therefore, better corporate social performance should correlate with a lower cost of debt.

Another stream of research views CSR as a form of investment (McWilliams and Siegel 2001). As such, the value of CSR can be evaluated through the principle of the net present value (NPV) approach (Harris and Raviv 1996). The NPV rule states that a firm should undertake projects with positive NPVs when the value of the discounted cash that flows from its future income streams outweighs the cost of conducting such investment (Hirshleifer 1961; Ross 1978). Numerous empirical studies attempt to identify the financial consequences of CSR investments (Barnett and Salomon 2006; Brammer and Millington 2008; Surroca et al. 2010; Waddock and Graves 1997). For example, one perspective (McWilliams and Siegel 2001) stresses that the costs of CSR-related investments may offset the potential benefits (i.e., zero NPV). Another perspective (Barnea and Rubin 2005) based on agency theory suggests that a firm manager may overinvest in CSR activities to pursue private benefit at the expense of shareholders (i.e., negative NPV). Nonetheless, a recent research by Li et al. (2016) documented that firms with powerful CEOs do not necessarily engage more in CSR activities, which is contrary to what agency theory suggests. Therefore, although there is some evidence that firms integrating various stakeholders' interests in their business operations make better CSR investments, the positive relation between CSR activities and firm performance is not guaranteed. In other words, under certain circumstances, we may observe an insignificant or even positive relation between a firm's CSR profile and the cost of debt.

A third view highlights the potential externalities of socially irresponsible activities (Chava 2014). Instead of making investments in CSR activities to develop strengths in certain dimensions of socially desirable outcomes, some firms experience significant concerns due to socially irresponsible actions. For example, firms may have inferior performance in their environmental management by the emission of toxic chemicals and hazardous waste. In another instance, firms may have a bad reputation in committing to fair employee treatment. Concerns regarding a firm's CSR profile may expose a firm to higher risk such as an increased likelihood of litigation. Debt holders may view CSR concerns as an indicator of heightened uncertainty of repaying the debt, and thus demand a higher premium to compensate for bearing more risk.

In summary, the relation between borrowing firms' CSR profiles and the cost of debt is ambiguous, and is thereby an empirical question. Despite the limited research along this line, investigating how institutional investors assess issuing firms' corporate social performance in the context of privately placed bonds allows us to offer new insights into the existing literature. For example, should firms 
devote more resources to satisfy stakeholder demands through CSR initiatives, so that "more is always better" (Harrison and Bosse 2013)? If not, how much is too much? Moreover, firms issuing securities under Rule $144 \mathrm{~A}$ are likely to be financially constrained, and the benefits of allocating resources to CSR activities may not justify the cost. It is plausible that these firms may have limited resources to manage stakeholder relationships, and thus result in significant concerns for important stakeholder groups. Will the externalities of socially irresponsible actions adversely affect the cost of debt issued under Rule 144A? In this study, we tend to conduct an empirical investigation to shed some further light on these important issues.

\section{Data, Sample, and Measures}

\subsection{Data and Sample}

We rely on various data sources to construct our sample. We retrieve information on bond issuances under Rule 144A from the Thomson Reuters SDC Platinum New Issue Database (SDC). We focus on bonds issued by publicly traded firms in the United States, and require our sample bonds to be non-convertible, with a fixed coupon rate and maturity longer than one year. We collect data items such as the issuing company's identity, bond yield, maturity, issue size, and credit rating from the SDC database (Albring et al. 2011; Arena 2011; Chandra and Nayar 2008; Chou and Chen 2014).

We match the bond issuance data from the SDC with the KLD Research \& Analytics (KLD) database according to the issuers' names, IDs, and ticker symbols. We further supplement our matched sample with the Compustat database to retrieve necessary financial information. Following the convention, we eliminate financial firms (SIC codes 6000-6999) and utility firms (SIC codes 4900-4999), because firms in these industry segments are highly regulated. Our sampling procedure yields 899 bond issuances under Rule144A by 645 unique firms in the period from 1998 to 2013.

\subsection{Measures}

The dependent measure is the cost of bond (i.e., yield spread expressed as basis points) at issuance, which is calculated as the bond yield over the yield of a treasury bond with a similar issuing date and maturity. We further take the natural logarithm of yield spread to normalize the distribution and ease the interpretation of our results.

In line with the existing literature (Becchetti et al. 2013; Deng et al. 2013; Greg et al. 2009), we reply on the KLD database to calculate our main explanatory variables. While the KLD dataset is subject to various critics, it is widely adopted by practitioners and academics to obtain objective measures of CSR-related activities and corporate social performance. KLD uses multiple information sources to rate firms across seven broad categories including the environment, community, corporate governance, human rights, employee relations, diversity, and product quality and safety (Goss and Roberts 2011; Hillman and Keim 2001). For each category, KLD assigns scores (1/0) for different items according to whether a firm has a concern or a strength along that dimension. We sum up all of the strengths (concerns) for the six dimensions, excluding corporate governance, to obtain CSR_strengths score (CSR_concerns score). Considering that KLD claims that the rating reflects CSR activities at the calendar year-end, we measure CSR_strengths and CSR_Concern with a one-year lag. In the regression analysis, we take the natural logarithm of CSR variables to normalize the distributions (Chan et al. 2014).

In the regression analysis, we control for two sets of variables capturing various aspects of firm characteristics and bond contractual features. We include firm size, Tobin's $Q$, book leverage, profitability, and sales growth rate as the first set of variables. Specifically, firm size is measured as the natural logarithm of the book value of firm assets. We include Tobin's $Q$ as a proxy for firm growth potential, which is calculated as the firm market capitalization divided by the book value of the asset. We measure firm book leverage as total debt divided by the book value of firm assets. We use return on assets (ROA) as the proxy for firm profitability. In addition, we measure the firm sales growth rate as the percentage change of firm net sales from year $t-1$ to year $t$. In the second set of variables, 
we calculate the issuing size as the natural logarithm of bond proceeds at issuance. Debt maturity is measured as the natural logarithm of the number of years from issuance to maturity. Following Arena (2011), we include a numerical variable to reflect the debt rating of bond issuers, with 22 for grade AAA rating and one for grade $\mathrm{D}$ rating.

\subsection{Summary Statistics and Univariate Test}

Table 1 reports the summary statistics of our sample. The Rule 144A bond issuances in our sample have a mean yield spread of 380 basis points and with an average maturity of 9.2 years. The means of CSR_strengths and CSR_concerns are 1.303 and 1.789, respectively. Preliminarily, the results indicate for our sample bond issuances that the concerns in CSR-related activities is more of an issue, because CSR_strengths' scores net of CSR_concerns scores are on average negative. It is worth noting that the mean difference between CSR_strengths and CSR_concerns for issuers of Rule 144A debt offerings is -0.486 , whereas the mean difference of CSR_strengths and CSR_concerns for issuers of public bonds is 1.798 as shown in Table 2.

Table 1. Summary statistics.

\begin{tabular}{ccccc}
\hline Variables & N & Mean & St Dev & p50 \\
\hline Yield spread (bps) & 892 & 379.956 & 232.071 & 334.000 \\
CSR_strengths & 892 & 1.303 & 2.154 & 0.000 \\
CSR_concerns & 892 & 1.789 & 1.714 & 1.000 \\
Firm size & 892 & 8.228 & 1.196 & 8.119 \\
Tobin's Q & 892 & 1.563 & 0.829 & 1.324 \\
Profitability & 892 & 0.128 & 0.073 & 0.120 \\
Sales growth rate & 892 & 0.622 & 7.031 & 0.106 \\
Book leverage & 892 & 0.384 & 0.157 & 0.367 \\
Maturity (years) & 892 & 9.214 & 4.764 & 8.181 \\
Debt rating & 892 & 10.920 & 3.293 & 10.000 \\
Issuing size (\$ mil) & 892 & 631.553 & 1048.566 & 321.088 \\
\hline
\end{tabular}

This paper provides descriptive statistics for variables used in regression analyses. Yield spread is the bond yield in basis points at the issuance subtracting the yield of treasure bond with similar issuing date and maturity. CSR_stengths (CSR_conerns) is the sum of all of the scores in different categories, capturing the strengths (concerns) of a firm's corporate social responsibility (CSR) activities in the KLD database. Firm size refers to the natural logarithm of book assets. Tobin's Q is measured as firm market capitalization divided by the book value of firm assets. Profitability is measured as firm return on assets. Sales growth rate is measured as the percentage change of firm net sales from year $t-1$ to year $t$. Book leverage is the ratio of total debt over the book value of firm assets. Maturity is the number of years from bond issuance to maturity. Debt rating is the Standard \& Poor's (S\&P) long-term debt rating with 22 for grade AAA and 1 for grade D. Issuing size is the bond proceeds.

Table 2. Univariate tests.

\begin{tabular}{ccccc}
\hline Variables & $\begin{array}{c}\text { Rule 144A Bonds } \\
(\mathbf{N}=\mathbf{8 9 2})\end{array}$ & $\begin{array}{c}\text { Public Bonds } \\
(\mathbf{N}=\mathbf{3 1 1 2})\end{array}$ & Mean Difference & $\boldsymbol{t}$ Statistics \\
\hline Yield spread & 379.956 & 173.503 & $206.5^{* * *}$ & 33.202 \\
CSR strength & 1.303 & 4.816 & $-3.513^{* * *}$ & -24.450 \\
CSR concern & 1.789 & 3.018 & $-1.229^{* * *}$ & -12.790 \\
Firm size & 8.230 & 9.733 & $-1.504^{* * *}$ & -32.712 \\
Tobin's Q & 1.562 & 1.958 & $-0.396^{* * *}$ & -11.076 \\
Profitability & 0.128 & 0.158 & $-0.0294^{* * *}$ & -11.409 \\
Sales growth rate & 0.623 & 5.515 & -4.892 & -1.205 \\
Book leverage & 0.384 & 0.301 & $0.0828^{* * *}$ & 16.999 \\
Years to maturity & 9.213 & 11.596 & $-2.383^{* * *}$ & -7.283 \\
Debt rating & 10.920 & 15.735 & $-4.816^{* * *}$ & -41.981 \\
Issue size & 632.010 & 1218.347 & $-586.3^{* * *}$ & -6.620 \\
\hline
\end{tabular}

*** $p<0.01$. This table reports the univariate tests of key variables for firms issuing bonds issued under Rule 144A and firms issuing bonds in the public market. CSR_stengths (CSR_conerns) is the sum of all of the scores in different categories, capturing the strengths (concerns) of a firm's CSR activities in the KLD database. Firm size is measured as the natural logarithm of book assets. Tobin's $Q$ is measured as firm market capitalization divided by the book value of firm assets. Profitability is measured as firm return on assets. Sales growth rate is measured as the percentage change of firm net sales from year $t-1$ to year $t$. Book leverage is the ratio of total debt over book value of firm assets. Maturity is the number of years from bond issuance to maturity. Debt rating is the S\&P long-term debt rating with 22 for grade AAA and one for grade D. Issuing size is the bond proceeds. 
To reveal some of the uniqueness of our sample bonds, we conducted a univariate analysis to compare bonds issued under Rule 144A and bonds issued to public markets. We chose a matching group of public bonds $(\mathrm{N}=3112)$ issued in the same year and with similar bond contractual features, including the size of issuance and maturity. As shown in the table, on average, the yield spread of bonds issued under Rule 144A is higher than that of public bonds by 206 basis points. Consistent with previous studies (Denis and Mihov 2003; Livingston and Zhou 2002), bond issuers under Rule $144 \mathrm{~A}$ tend to have lower credit quality in terms of debt rating. Bonds issued under Rule 144A have short maturity and a smaller issuing size. Firms issuing bonds under Rule 144A tend to engage less in CSR-related activities, have less growth potential, and be less profitable. Overall, the results reported in Table 2 indicate that bond issuances as well as bond issuers are quite different from those made through public offerings (Denis and Mihov 2003).

\section{Results}

\subsection{Regression Analyses Relating Bond Yield Spread at Issuance to Firm CSR Scores}

Table 3 reports the baseline regression results relating bond yield spread at issuance under Rule 144A to the CSR involvement of bond issuers. Specifically, we model the bond yield spread as a function of firm CSR scores along with variables capturing various aspects of firm characteristics and bond contractual features (Equation (1)). We use the Stata software package to perform our regression analyses. In all of the model specifications, we include year fixed effects $\left(\theta_{t}\right)$ to control for the timely trend and economy-wide shocks. We also add industry fixed effects at the two-digit SIC level $\left(\eta_{j}\right)$ to absorb all of the industry-level unobservable but time-invariant factors. In addition, we cluster the standard error by firm to control for the possibility that the errors may correlate for the bonds issued by the same firm over time (Petersen 2009).

$$
\begin{array}{ll}
\text { Bond yield spread } & \text { at issuance } \\
& =\alpha+\beta * \text { CSR score }+\gamma * \text { Firm characteristics } \\
& +\phi * \text { Bond characteristics }+\eta_{j}+\theta_{t}+\varepsilon
\end{array}
$$

In columns 1 and 2, we enter CSR_strengths and CSR_concerns separately with controls only for firm characteristics. It appears that CSR_strengths is insignificant in determining bond yield spread (column 1). The results cannot reject neither a risk mitigation hypothesis nor an overinvestment hypothesis. Note that our sample issuing firms have lower credit quality, less profitability, and engage less in CSR-related activities. It is plausible that investors view investments in CSR activities by our sample firms as less attractive because such investments divert scarce resources to non-productive activities. Even if investments in CSR can mitigate firm risk exposure, the benefit can be offset by excessive engagement in CSR-related activities. Strikingly, we document a significant and negative coefficient on CSR_concerns (column 2). It appears that the externalities of CSR activities expose issuing firms to environmental, social, or stakeholder concerns, which result in a higher bond yield spread demanded by investors (Chava 2014; Goss and Roberts 2011). We replicate our regression analyses in columns 3 and 4 by adding controls for the debt contractual features, and we generally find consistent results. Overall, the results in Table 3 indicate that the qualified institutional investors do assess information in a firm's CSR policy, and demand higher spreads for higher CSR concerns (Goss and Roberts 2011).

In a similar study, Amiraslani et al. (2018) reported an insignificant relation between CSR and bond spreads in the period 2005-2013, and argued that CSR activities only help reduce the bond spreads in the financial crisis (i.e., 2008-2009). Goss and Roberts (2011) documented that the CSR scores related to concerns have a significantly positive effect on the cost of bank loans. It seems that the effects of CSR on the firm cost of debt vary in different contexts. It is plausible that banks as delegated monitors and inside lenders have the expertise to extract information from borrowers' CSR profiles to facilitate the lending decisions. However, as a means of arm's length financing, investors of 
public bonds rely more on rating agencies' assessment to gauge the riskiness of the issuance and price the bond accordingly. In the context of private placement under Rule $144 \mathrm{~A}$, the bond investors are sophisticated institutional investors, and they resemble the banks in loan contracts in terms of their ability to interpret the information content of issuing firms' CSR profiles (Goss and Roberts 2011).

Table 3. Baseline regressions relating CSR to bond yield spread at issuance under Rule 144A.

\begin{tabular}{|c|c|c|c|c|}
\hline \multirow{2}{*}{ Independent Variables } & \multicolumn{4}{|c|}{ Dependent Variable: Yield Spread (in logs) } \\
\hline & (1) & (2) & (3) & (4) \\
\hline CSR_strengths & $\begin{array}{c}-0.033 \\
(0.039)\end{array}$ & & $\begin{array}{l}-0.011 \\
(0.039)\end{array}$ & \\
\hline CSR_concerns & & $\begin{array}{c}0.110 * * * \\
(0.037)\end{array}$ & & $\begin{array}{c}0.129 * * * \\
(0.036)\end{array}$ \\
\hline Firm size & $\begin{array}{c}-0.182^{* * *} \\
(0.023)\end{array}$ & $\begin{array}{c}-0.216^{\text {*** }} \\
(0.021)\end{array}$ & $\begin{array}{c}-0.156^{* * *} \\
(0.027)\end{array}$ & $\begin{array}{c}-0.180^{* * *} \\
(0.025)\end{array}$ \\
\hline Tobin's Q & $\begin{array}{c}-0.178^{* * *} \\
(0.035)\end{array}$ & $\begin{array}{c}-0.175^{* * *} \\
(0.035)\end{array}$ & $\begin{array}{c}-0.121^{* * *} \\
(0.034)\end{array}$ & $\begin{array}{c}-0.110^{* * *} \\
(0.034)\end{array}$ \\
\hline Profitability & $\begin{array}{c}-1.079 * * * \\
(0.346)\end{array}$ & $\begin{array}{c}-1.084^{* * *} \\
(0.335)\end{array}$ & $\begin{array}{c}-1.021^{* * *} \\
(0.352)\end{array}$ & $\begin{array}{c}-1.014^{* * *} \\
(0.337)\end{array}$ \\
\hline Sales growth rate & $\begin{array}{c}-0.002 * * * \\
(0.001)\end{array}$ & $\begin{array}{c}-0.002^{* * *} \\
(0.001)\end{array}$ & $\begin{array}{c}-0.002 * * * \\
(0.001)\end{array}$ & $\begin{array}{c}-0.002^{* * *} \\
(0.001)\end{array}$ \\
\hline Book leverage & $\begin{array}{c}0.890 * * * \\
(0.145)\end{array}$ & $\begin{array}{c}0.901 * * * \\
(0.144)\end{array}$ & $\begin{array}{c}0.864^{* * *} \\
(0.142)\end{array}$ & $\begin{array}{c}0.881^{* * *} \\
(0.141)\end{array}$ \\
\hline Maturity & & & $\begin{array}{c}0.003 \\
(0.004)\end{array}$ & $\begin{array}{c}0.004 \\
(0.004)\end{array}$ \\
\hline Issuing size & & & $\begin{array}{c}-0.000 \\
(0.000)\end{array}$ & $\begin{array}{c}-0.000^{* *} \\
(0.000)\end{array}$ \\
\hline Debt rating & & & $\begin{array}{c}-0.475^{* * *} \\
(0.104)\end{array}$ & $\begin{array}{c}-0.495^{* * *} \\
(0.101)\end{array}$ \\
\hline Constant & $\begin{array}{c}6.984^{* * *} \\
(0.241)\end{array}$ & $\begin{array}{c}7.137^{* * * *} \\
(0.236)\end{array}$ & $\begin{array}{c}6.780^{* * * *} \\
(0.244)\end{array}$ & $\begin{array}{c}6.839 * * * \\
(0.238)\end{array}$ \\
\hline Year fixed effect & Yes & Yes & Yes & Yes \\
\hline Industry fixed effect & Yes & Yes & Yes & Yes \\
\hline Observations & 892 & 892 & 892 & 892 \\
\hline Adjusted R-squared & 0.627 & 0.633 & 0.648 & 0.657 \\
\hline
\end{tabular}

\begin{abstract}
*** $p<0.01, * * p<0.05, * p<0.1$. Note the CSR-related activities are a voluntary business decision. In this table, we report the baseline regression rating issuing firms' CSR profiles to the bond yield spread at issuance under Rule 144A. The dependent variable is the natural logarithm of yield spread at issuance. CSR_stengths (CSR_conerns) is the sum of all of the scores in different categories capturing the strengths (concerns) of a firm's CSR activities in the KLD database. Firm size indicates the natural logarithm of book assets. Tobin's Q is measured as firm market capitalization divided by book value of firm assets. Profitability is measured as firm return on assets. Sales growth rate is measured as the percentage change of firm net sales from year $t-1$ to year $t$. Book leverage is the ratio of total debt over the book value of firm assets. Maturity is the number of years from bond issuance to maturity. Debt rating is the S\&P long-term debt rating with 22 for grade AAA and one for grade D. Issuing size is the bond proceeds. Clustered standard errors by issuers are reported in parentheses.
\end{abstract}

Regarding other control variables, our results are generally consistent with the existing literature (Francis et al. 2018; Goss and Roberts 2011). For example, issuing firms experience a lower bond yield spread at issuance when they are larger, more profitable, have a lower debt ratio, and have a higher sales growth rate.

Therefore, the endogeneity issue arises in the baseline regression analysis and can potentially bias the estimation. As Li et al. (2016) suggested, several approaches exist to address the endogeneity issue, which include general method of moments (GMM) estimation, the instrumental variable approach, fixed effect analysis, dynamic panel with lagged dependent variable, and the inclusion of more controls to alleviate omitted variable problems. GMM estimation, fixed effects, and dynamic panel estimation require a panel data structure to obtain consistent estimation. However, our sample consisting of 899 bond issuances by 645 unique issuers is closer to the cross-sectional data, and makes it difficult to implement the above-mentioned three approaches. Therefore, we adopted an instrument variable 
approach in our estimation (El Ghoul et al. 2011; Goss and Roberts 2011). In particular, following Rubin (2008) and Di Giuli and Kostovetsky (2014), we used the state voting records as the instrument variable of the firm's CSR involvement. Rubin (2008) found that companies with a high CSR rating tend to be located in democratic states, whereas companies with a low CSR rating tend to be located in republican states. We use state-level voting record for Republican or Democratic as a valid instrument, because the preference in state voting is likely to influence a firm's CSR involvement, but is unlikely to have a direct effect on the cost of bond issuance. Specifically, for each state, we calculated the percentage of votes for Republican as our instrument. Since voting records are only available for the election years, for non-election years, we used voting records in the immediately following election year to calculate the instrument variable.

Table 4 reports the second stage regression results with CSR_strengths and CSR_concerns being instrumented by the state voting record of voting Republican, as detailed above. We only control for firm characteristics in columns 1 and 3, and add additional controls for bond contractual features in columns 2 and 4. We document significant and positive coefficients on instrumented CSR_concerns in both columns 3 and 4 . The findings based on the instrument variable approach are generally consistent with our findings reported in Table 3. We also documented a significant and negative coefficient on CSR_strengths, although the significance is only marginal $(p<0.10)$. In addition, we note that the coefficients of firm size in columns 1 and 2 become insignificant. A recent research by Dang et al. (2018) did a comprehensive investigation regarding the effects of various measures of firm size on empirical corporate finance, and concluded that the choices of measures of firm size matter. Therefore, in order to ensure the robustness of our findings, we used firm market capitalization (logged) as an alternative measure of firm size, and found qualitatively similar results (results not reported). Moreover, we found a relatively high correlation between CSR_strengths and firm size, which reflects that large firms may engage more in CSR activities to build their strengths in fulfilling the demand of multiple stakeholder groups. It is plausible that firm size takes away the significance of CSR_strengths in Table 3. As evidenced in columns 1 and 2 in Table 4, once the CSR_strengths factor is instrumented, the coefficients of CSR_strengths become marginally significant and negative, and the significance of firm size vanishes.

Moreover, for IV estimations, we conduct several post-estimation diagnostic tests to ensure the appropriateness of our choice of IVs. The significant Durbin-Wu-Hausman test statistics that are reported in Table 4 indicate that the CSR variables are indeed endogenous, and other unobservable variables exist and have a strong influence on firms' decision to engage in CSR activities. Therefore, it is appropriate to treat CSR variables as endogenous, and adopt the IV approach to address the issue. We further report the coefficients for the IVs in the first-stage regression and Kleibergen-Paaprk Wald F-statistics for the weak identification test. The significant coefficients of our IVs and large F-values indicate that the chosen instruments are strongly relevant. Additionally, the Kleibergen-Paaprk Lagrange multiplier (LM) statistics suggest that our regression models are well specified and not subject to the under-identification problem (Kleibergen and Paap 2006). After controlling for the endogeneity issue, we still found a significant and positive relation between CSR_concerns and bond yield spread at issuance. We also note that the effects of CSR_strengths on bond yield spread at issuance turns out to be negative $(p<0.10)$, which further manifests the necessity to address the endogeneity issue in order to obtain consistent estimation.

It is also plausible that price term (i.e., bond yield spread at issuance) and non-price term (maturity) are simultaneously determined. Our estimate can be biased if we fail to control for the simultaneity in the design of bond contracts (Dennis et al. 2000; Goss and Roberts 2011). We adopt a structural framework to accommodate the simultaneous determination of bond yield spreads and maturity (Bharath et al. 2011; Degryse and Ongena 2001). Specifically, we assume that bond maturity affects bond yield, and bond maturity can also be separately determined. Following the existing literature (Bharath et al. 2011), we estimate a system of equations through a three-stage least squares (3SLS) estimator, and report the estimation results in Table 5. 
Table 4. Addressing the endogeneity issue: an instrumental variable approach.

\begin{tabular}{|c|c|c|c|c|}
\hline \multirow{2}{*}{ Independent Variables } & \multicolumn{4}{|c|}{ Dependent Variable: Yield Spread (in logs) } \\
\hline & (1) & (2) & (3) & (4) \\
\hline CSR_strengths (Instrumented) & $\begin{array}{l}-1.203 * \\
(0.633)\end{array}$ & $\begin{array}{l}-1.067^{*} \\
(0.544)\end{array}$ & & \\
\hline CSR_concerns (Instrumented) & & & $\begin{array}{c}0.971 * * \\
(0.393)\end{array}$ & $\begin{array}{l}0.984^{* *} \\
(0.408)\end{array}$ \\
\hline Firm size & $\begin{array}{c}0.178 \\
(0.196)\end{array}$ & $\begin{array}{c}0.086 \\
(0.126)\end{array}$ & $\begin{array}{c}-0.400 * * * \\
(0.084)\end{array}$ & $\begin{aligned}- & 0.326^{* * *} \\
& (0.071)\end{aligned}$ \\
\hline Tobin's Q & $\begin{array}{c}0.003 \\
(0.106)\end{array}$ & $\begin{array}{c}0.011 \\
(0.075)\end{array}$ & $\begin{array}{l}-0.109 \text { ** } \\
(0.044)\end{array}$ & $\begin{array}{l}-0.030 \\
(0.050)\end{array}$ \\
\hline Profitability & $\begin{array}{c}-0.849^{*} \\
(0.462)\end{array}$ & $\begin{array}{l}-0.911 \text { ** } \\
(0.420)\end{array}$ & $\begin{array}{l}-1.074^{* * *} \\
(0.305)\end{array}$ & $\begin{array}{l}-0.963^{* * *} \\
(0.295)\end{array}$ \\
\hline Sales growth rate & $\begin{array}{l}-0.001 * \\
(0.001)\end{array}$ & $\begin{array}{l}-0.002 * * * \\
(0.001)\end{array}$ & $\begin{array}{l}-0.002 * * \\
(0.001)\end{array}$ & $\begin{array}{l}-0.002 * * * \\
(0.001)\end{array}$ \\
\hline Book leverage & $\begin{array}{l}0.717^{* * *} \\
(0.212)\end{array}$ & $\begin{array}{l}0.601 * * * \\
(0.223)\end{array}$ & $\begin{array}{l}0.946^{* * *} \\
(0.150)\end{array}$ & $\begin{array}{l}0.979^{* * *} \\
(0.156)\end{array}$ \\
\hline Maturity & & $\begin{array}{l}-0.005 \\
(0.007)\end{array}$ & & $\begin{array}{c}0.009 \\
(0.006)\end{array}$ \\
\hline Issuing size & & $\begin{array}{c}0.000 \\
(0.000)\end{array}$ & & $\begin{array}{l}-0.000 * * * \\
(0.000)\end{array}$ \\
\hline Debt rating & & $\begin{array}{l}-0.226 \\
(0.195)\end{array}$ & & $\begin{array}{l}-0.610^{* * *} \\
(0.121)\end{array}$ \\
\hline Constant & $\begin{array}{l}5.018^{* * *} \\
(1.381)\end{array}$ & $\begin{array}{l}5.643^{* * *} \\
(0.846)\end{array}$ & $\begin{array}{l}8.218^{* * *} \\
(0.315)\end{array}$ & $\begin{array}{l}7.504^{* * *} \\
(0.238)\end{array}$ \\
\hline Year fixed effect & Yes & Yes & Yes & Yes \\
\hline Industry fixed effect & Yes & Yes & Yes & Yes \\
\hline $\begin{array}{c}\text { Observations } \\
\text { Adjusted R-squared }\end{array}$ & $\begin{array}{c}892 \\
0.167\end{array}$ & $\begin{array}{c}892 \\
0.196\end{array}$ & $\begin{array}{c}892 \\
0.193\end{array}$ & $\begin{array}{c}892 \\
0.231\end{array}$ \\
\hline Durbin-Wu-Hausman (endogeneity test) & $\begin{array}{c}10.007 \\
(p<0.01)\end{array}$ & $\begin{array}{c}9.984 \\
(p<0.01)\end{array}$ & $\begin{array}{c}8.228 \\
(p<0.01)\end{array}$ & $\begin{array}{c}7.68 \\
(p<0.01)\end{array}$ \\
\hline Kleibergen-Paaprk LM statistic (under-identification test) & $\begin{array}{c}5.98 \\
(p<0.05)\end{array}$ & $\begin{array}{c}7.394 \\
(p<0.01)\end{array}$ & $\begin{array}{c}10.501 \\
(p<0.01)\end{array}$ & $\begin{array}{c}10.398 \\
(p<0.01)\end{array}$ \\
\hline First-stage coefficient of instrument & $\begin{array}{c}-2.191 \\
(p<0.05)\end{array}$ & $\begin{array}{c}-2.443 \\
(p<0.01)\end{array}$ & $\begin{array}{c}3.14 \\
(p<0.01)\end{array}$ & $\begin{array}{c}2.98 \\
(p<0.01)\end{array}$ \\
\hline Kleibergen-Paaprk Wald F statistic (weak identification test) & $\begin{array}{c}4.804 \\
(p<0.05)\end{array}$ & $\begin{array}{c}5.963 \\
(p<0.01)\end{array}$ & $\begin{array}{c}9.894 \\
(p<0.01)\end{array}$ & $\begin{array}{c}8.911 \\
(p<0.01)\end{array}$ \\
\hline
\end{tabular}

${ }^{* * *} p<0.01,{ }^{* *} p<0.05,{ }^{*} p<0.1$. In this table, we used the instrumental variable approach to address the endogeneity issue. The dependent variable is the natural logarithm of yield spread at issuance. CSR_stengths (CSR_conerns) is the sum of all of the scores in different categories capturing the strengths (concerns) of a firm's CSR activities in the KLD database. We use the state voting records in the presidential election as the instrument variable of the firm's CSR involvement. Firm size is measured as the natural logarithm of book assets. Tobin's Q is measured as firm market capitalization divided by the book value of firm assets. Profitability is measured as firm return on assets. Sales growth rate is measured as the percentage change of firm net sales from year $t-1$ to year $t$. Book leverage is the ratio of total debt over the book value of firm assets. Maturity is the number of years from bond issuance to maturity. Debt rating is the S\&P long-term debt rating, with 22 for grade AAA and one for grade D. Issuing size is the bond proceeds. Clustered standard errors by issuers are reported in parentheses.

In Table 5, we focus on CSR_strengths and CSR_concerns in columns 1-2 and columns 3-4, respectively. Generally, we find that maturity is positively correlated with bond yield spread at issuance. It is plausible that investors may demand a higher yield for bonds with longer maturity because the associated risk exposure will be higher. Nonetheless, this model specification does not take away our main findings. Taken as a whole, results reported in Tables 3-5 indicate that higher CSR concerns are associated with higher bond spreads. Moreover, across different model specifications, CSR strengths are generally insignificant. 
Table 5. Simultaneous determination of bond yield spread and maturity: three-stage least squares (3SLS) estimation.

\begin{tabular}{|c|c|c|c|c|}
\hline \multirow{3}{*}{ Independent Variables } & \multicolumn{4}{|c|}{ Dependent Variables } \\
\hline & Yield Spread & Maturity & Yield Spread & Maturity \\
\hline & (1) & (2) & (3) & (4) \\
\hline Maturity & $\begin{array}{c}0.045^{* *} \\
(0.018)\end{array}$ & & $\begin{array}{l}0.056^{* *} \\
-0.028\end{array}$ & \\
\hline CSR strengths & $\begin{array}{c}0.011 \\
(0.029)\end{array}$ & $\begin{array}{l}-0.249 \\
(0.607)\end{array}$ & & \\
\hline CSR concerns & & & $\begin{array}{c}0.118^{* * *} \\
-0.03\end{array}$ & $\begin{array}{c}-1.970 * \\
-1.094\end{array}$ \\
\hline Firm size & $\begin{array}{c}-0.171^{* * *} \\
(0.020)\end{array}$ & $\begin{array}{c}3.747^{* *} \\
(1.662)\end{array}$ & $\begin{array}{c}-0.195^{* * *} \\
-0.021\end{array}$ & $\begin{array}{l}3.237 * \\
-1.777\end{array}$ \\
\hline Tobin's Q & $\begin{array}{c}-0.137^{* * *} \\
(0.021)\end{array}$ & $\begin{array}{l}2.986 * \\
(1.546)\end{array}$ & $\begin{array}{c}-0.124^{* * *} \\
-0.021\end{array}$ & $\begin{array}{c}2.026 \\
-1.346\end{array}$ \\
\hline Profitability & $\begin{array}{c}-1.497^{* * *} \\
(0.230)\end{array}$ & $\begin{array}{c}32.738^{* *} \\
(15.376)\end{array}$ & $\begin{array}{c}-1.530 * * * \\
-0.241\end{array}$ & $\begin{array}{l}25.353 * \\
-14.065\end{array}$ \\
\hline Sales growth rate & $\begin{array}{l}-0.001 \\
(0.002)\end{array}$ & $\begin{array}{c}0.032 \\
(0.046)\end{array}$ & $\begin{array}{l}-0.001 \\
-0.002\end{array}$ & $\begin{array}{c}0.018 \\
-0.036\end{array}$ \\
\hline Book leverage & $\begin{array}{c}1.035^{* * *} \\
(0.110)\end{array}$ & $\begin{array}{c}-22.626^{* *} \\
(11.023)\end{array}$ & $\begin{array}{c}1.042^{* * *} \\
-0.112\end{array}$ & $\begin{array}{c}-17.177 \text { * } \\
-10.2\end{array}$ \\
\hline Issue size & $\begin{array}{c}-0.000 * * * \\
(0.000)\end{array}$ & $\begin{array}{c}0.002 \text { ** } \\
(0.001)\end{array}$ & $\begin{array}{c}-0.000^{* * *} \\
0\end{array}$ & $\begin{array}{c}0.002 * * \\
-0.001\end{array}$ \\
\hline Debt rating & $\begin{array}{c}-0.440 * * * \\
(0.070)\end{array}$ & $\begin{array}{l}9.620 * \\
(5.077)\end{array}$ & $\begin{array}{c}-0.453^{* * *} \\
-0.069\end{array}$ & $\begin{array}{c}7.424 \\
-4.836\end{array}$ \\
\hline Constant & $\begin{array}{c}6.812^{* * *} \\
(0.332)\end{array}$ & $\begin{array}{c}-148.737 \text { * } \\
(79.230)\end{array}$ & $\begin{array}{c}6.718^{* * *} \\
-0.375\end{array}$ & $\begin{array}{l}-109.556 \\
-74.006\end{array}$ \\
\hline Year fixed effect & Yes & Yes & Yes & Yes \\
\hline Industry fixed effect & Yes & Yes & Yes & Yes \\
\hline Observations & 892 & 892 & 892 & 892 \\
\hline Adjusted R-squared & 0.633 & 0.756 & 0.597 & 0.492 \\
\hline
\end{tabular}

${ }_{* * *} p<0.01,{ }^{* *} p<0.05,{ }^{*} p<0.1$. This table reports regression results using 3SLS estimator to estimate a system of two equations. The dependent variables are the natural logarithm of yield spread at issuance and bond maturity. CSR_stengths (CSR_conerns) is the sum of all of the scores in different categories capturing the strengths (concerns) of a firm's CSR activities in the KLD database. Firm size is measured as the natural logarithm of book assets. Tobin's $\mathrm{Q}$ is measured as firm market capitalization divided by the book value of firm assets. Profitability is measured as firm return on assets. Sales growth rate is measured as the percentage change of firm net sales from year $t-1$ to year $t$. Book leverage is the ratio of total debt over book value of firm assets. Maturity is the number of years from bond issuance to maturity. Debt rating is the S\&P long-term debt rating, with 22 for grade AAA and one for grade D. Issuing size is the bond proceeds. Clustered standard errors by issuers are reported in parentheses.

\subsection{Additional Robustness Checks}

In this section, we examine whether institutional investors also make use of information in the time-series changes of the firm CSR scores of our sample issuers. Over time, firms can invest in CSR activities to improve their corporate social performance. By doing so, firms can either increase their CSR profiles or limit their expose themselves to more social, environmental, or stakeholder issues. In Table 6, we link bond yield spread at issuance to the changes of CSR strengths and concerns over time. 
Table 6. Time-series changes in CSR profiles and bond yield spread at issuance under Rule 144A.

\begin{tabular}{|c|c|c|c|c|c|c|}
\hline \multirow{2}{*}{ Independent Variables } & \multicolumn{6}{|c|}{ Dependent Variable: Yield Spread (in logs) } \\
\hline & (1) & (2) & (3) & (4) & (5) & (6) \\
\hline$\Delta$ CSR_strengths $(t-3)$ & $\begin{array}{l}-0.003 \\
(0.018)\end{array}$ & & & & & \\
\hline$\Delta$ CSR_strengths $(t-4)$ & & $\begin{array}{c}0.007 \\
(0.022)\end{array}$ & & & & \\
\hline$\Delta$ CSR_strengths $(t-5)$ & & & $\begin{array}{c}0.000 \\
(0.020)\end{array}$ & & & \\
\hline$\Delta$ CSR_concerns $(t-3)$ & & & & $\begin{array}{c}0.037^{* *} \\
(0.016)\end{array}$ & & \\
\hline$\Delta$ CSR_concerns $(t-4)$ & & & & & $\begin{array}{c}0.0270 \text { ** } \\
(0.014)\end{array}$ & \\
\hline$\Delta$ CSR_concerns $(t-5)$ & & & & & & $\begin{array}{c}0.025 \\
(0.016)\end{array}$ \\
\hline Firm size & $\begin{array}{c}-0.121^{* * *} \\
(0.031)\end{array}$ & $\begin{array}{c}-0.110^{* * *} \\
(0.032)\end{array}$ & $\begin{array}{c}-0.123^{* * *} \\
(0.036)\end{array}$ & $\begin{array}{c}-0.114^{* * *} \\
(0.030)\end{array}$ & $\begin{array}{c}-0.128^{* * *} \\
(0.035)\end{array}$ & $\begin{array}{c}-0.123^{* * *} \\
(0.030)\end{array}$ \\
\hline Tobin's Q & $\begin{array}{c}-0.098^{* * *} \\
(0.035)\end{array}$ & $\begin{array}{c}-0.091 \text { ** } \\
(0.039)\end{array}$ & $\begin{array}{c}-0.074 * \\
(0.044)\end{array}$ & $\begin{array}{c}-0.087^{* *} \\
(0.041)\end{array}$ & $\begin{array}{l}-0.072 \\
(0.044)\end{array}$ & $\begin{array}{c}-0.097^{* * *} \\
(0.036)\end{array}$ \\
\hline Profitability & $\begin{array}{c}-1.192^{* * *} \\
(0.423)\end{array}$ & $\begin{array}{c}-1.157^{* *} \\
(0.493)\end{array}$ & $\begin{array}{c}-1.206 \text { ** } \\
(0.510)\end{array}$ & $\begin{array}{c}-1.169 * * \\
(0.499)\end{array}$ & $\begin{array}{c}-1.216^{* *} \\
(0.509)\end{array}$ & $\begin{array}{c}-1.192 * * * \\
(0.427)\end{array}$ \\
\hline Sales growth rate & $\begin{array}{c}0.034 \\
(0.061)\end{array}$ & $\begin{array}{c}0.007 \\
(0.067)\end{array}$ & $\begin{array}{l}-0.005 \\
(0.082)\end{array}$ & $\begin{array}{l}-0.003 \\
(0.070)\end{array}$ & $\begin{array}{l}-0.013 \\
(0.084)\end{array}$ & $\begin{array}{c}0.034 \\
(0.064)\end{array}$ \\
\hline Book leverage & $\begin{array}{c}0.859^{* * * *} \\
(0.171)\end{array}$ & $\begin{array}{c}0.904^{* * *} \\
(0.186)\end{array}$ & $\begin{array}{c}0.918^{* * * *} \\
(0.195)\end{array}$ & $\begin{array}{c}0.896^{* * *} \\
(0.183)\end{array}$ & $\begin{array}{c}0.901 * * * \\
(0.193)\end{array}$ & $\begin{array}{c}0.854^{* * *} \\
(0.170)\end{array}$ \\
\hline Maturity & $\begin{array}{c}0.004 \\
(0.005)\end{array}$ & $\begin{array}{c}0.003 \\
(0.005)\end{array}$ & $\begin{array}{c}0.001 \\
(0.005)\end{array}$ & $\begin{array}{c}0.003 \\
(0.004)\end{array}$ & $\begin{array}{c}0.001 \\
(0.005)\end{array}$ & $\begin{array}{c}0.004 \\
(0.005)\end{array}$ \\
\hline Issue size & $\begin{array}{c}-0.000 * \\
(0.000)\end{array}$ & $\begin{array}{c}-0.000 * * \\
(0.000)\end{array}$ & $\begin{array}{l}-0.000 \\
(0.000)\end{array}$ & $\begin{array}{c}-0.000 * \\
(0.000)\end{array}$ & $\begin{array}{l}-0.000 \\
(0.000)\end{array}$ & $\begin{array}{c}-0.000 * \\
(0.000)\end{array}$ \\
\hline Debt rating & $\begin{array}{c}-0.494^{* * *} \\
(0.114)\end{array}$ & $\begin{array}{c}-0.544^{* * *} \\
(0.116)\end{array}$ & $\begin{array}{c}-0.566^{* * *} \\
(0.130)\end{array}$ & $\begin{array}{c}-0.540 * * * \\
(0.114)\end{array}$ & $\begin{array}{c}-0.563 * * * \\
(0.128)\end{array}$ & $\begin{array}{c}-0.493^{* * *} \\
(0.114)\end{array}$ \\
\hline Constant & $\begin{array}{c}6.446^{* * *} \\
(0.297)\end{array}$ & $\begin{array}{c}6.351 * * * \\
(0.313)\end{array}$ & $\begin{array}{c}6.459^{* * *} \\
(0.345)\end{array}$ & $\begin{array}{c}6.343^{* * *} \\
(0.294)\end{array}$ & $\begin{array}{c}6.468^{* * *} \\
(0.323)\end{array}$ & $\begin{array}{c}6.443^{* * *} \\
(0.289)\end{array}$ \\
\hline Year fixed effect & Yes & Yes & Yes & Yes & Yes & Yes \\
\hline Firm fixed effect & Yes & Yes & Yes & Yes & Yes & Yes \\
\hline Observations & 590 & 512 & 460 & 590 & 512 & 460 \\
\hline Adjusted R-squared & 0.682 & 0.698 & 0.705 & 0.702 & 0.707 & 0.684 \\
\hline $\begin{array}{l}* * * p<0.01, * * p<0.05,^{*} \\
\text { profiles to bond yield sp } \\
\text { spread at issuance. CSR } \\
\text { the strengths (concerns) } \\
\text { changes in CSR-strength } \\
\text { to year } t-1 \text {. We use the } \\
\text { involvement. Firm size } \\
\text { divided by the book val } \\
\text { measured as the percent } \\
\text { over the book value of } \mathrm{f} \\
\text { is the S\&P long-term de } \\
\text { Clustered standard erro }\end{array}$ & $\begin{array}{l}\text { O.1. This tab } \\
\text { dd at issuance } \\
\text { tengths (CSR } \\
\text { f a firm's CSR } \\
\text { and CSR_con } \\
\text { tate voting rec } \\
\text { natural logar } \\
\text { of firm asset } \\
\text { change of fir } \\
\text { n assets. Matı } \\
\text { rating with 2 } \\
\text { py issuers are }\end{array}$ & $\begin{array}{l}\text { reports the re } \\
\text { nder Rule } 144 \\
\text { conerns) is the } \\
\text { activities in th } \\
\text { ens from yea } \\
\text { rds in preside } \\
\text { thm of book a } \\
\text { Profitability } \\
\text { net sales fron } \\
\text { ity is the num } \\
\text { for grade AA } \\
\text { eported in par }\end{array}$ & $\begin{array}{l}\text { ression result } \\
\text { The depende } \\
\text { sum of all of } t \\
\text { KLD databas } \\
-5 \text { to year } t \\
\text { tial election a } \\
\text { sets. Tobin's } \\
\text { measured as } \\
\text { year } t-1 \text { to y } \\
\text { er of years fr } \\
\text { and one for } \\
\text { ntheses. }\end{array}$ & $\begin{array}{l}\text { relating to th } \\
t \text { variable is } t \\
\text { e scores in d } \\
\text { The main e } \\
1 \text {, year } t- \\
\text { the instrume } \\
\text { s measured } \\
\mathrm{rm} \text { return on } \\
\mathrm{r} t \text {. Book lev } \\
\mathrm{n} \text { bond issua } \\
\text { ade D. Issuir }\end{array}$ & $\begin{array}{l}\text { ime-series ch } \\
\text { natural logar } \\
\text { erent categor } \\
\text { lanatory vari } \\
\text { o year } t-1 \text {, a } \\
\text { variable of th } \\
\text { firm market } \\
\text { ssets. Sales g } \\
\text { age is the rati } \\
\text { ce to maturity } \\
\text { size is the bc }\end{array}$ & $\begin{array}{l}\text { ges in CSR } \\
\text { Im of yield } \\
\text { capturing } \\
\text { les are the } \\
\text { year } t-3 \\
\text { firm's CSR } \\
\text { italization } \\
\text { wth rate is } \\
\text { f total debt } \\
\text { Debt rating } \\
\text { l proceeds. }\end{array}$ \\
\hline
\end{tabular}

We adopt a three-year window to measure the changes of CSR strengths for year $t-4$ to year $t-1$, with year $t$ being the year of bond issuance. In addition, we measure the changes with a four-year window and a five-year window. For CSR concerns, we follow the same approach to measure the changes in different time windows. In columns $1-3$ of Table 6 , we focus on the changes in CSR 
strengths, and in columns 4-6, we focus on the changes in CSR concerns. Our results indicate that the increased number of CSR concerns over the past three-year and four-year windows results in a higher bond yield spread at issuance. It appears that institutional investors tend to demand a higher premium on bonds issued under Rule 144A, if the issuing firms expose themselves to more environmental, social, and stakeholder risk due to socially irresponsible activities. In addition, we find that the improvement of CSR strengths is not significantly correlated with bond yield spread. It is plausible that, from institutional investors' point of view, the benefits of improved corporate social performance do not justify the incurred cost of allocating extra resources to CSR-related activities.

Given that institutional investors demand a higher bond yield spread for bonds issued by firms facing greater concerns for environmental, social, and stakeholder risks, we further explore the sources of increased risk exposure in this section, and report our results in Table 7.

Existing studies have found that stakeholder risk associated with CSR activities may negatively affect a firm's volatility and the cost of bank loans (Becchetti et al. 2015; Goss and Roberts 2011). Firms engaging in CSR-related activities adopt a more complex strategy of stakeholder satisfaction. Firms taking socially responsible actions may set priorities on the demand of different stakeholder groups in order to retain their willful participation in productive operations (Harrison et al. 2010). Conflicts exist among various stakeholder groups when firms cannot fulfill their demands. Therefore, certain CSR concerns may indicate the level of stakeholder risk. Following Becchetti et al. (2015), we focus on the following KLD items: COM-con-A, COM-con-B, COM-con-C, COM-con-D, COM-con-X, DIV-con-A, DIV-con-X, EMP-con-B, EMP-con-X, ENV-con-X, HUM-con-D, HUM-con-F, HUM-con-G, HUM-con-X, PRO-con-A, PRO-con-D, and PRO-con-E, PRO-con-X. For each item, the KLD assigns a binary score $(1 / 0)$, with one indicating that a particular firm has a concern for that time. We measured stakeholder risk as the sum of the scores for all of the items, and then scale the total number of concerns by the total number (18) of items.

In addition, we also made a distinction between a firm's primary stakeholder groups and secondary stakeholder groups. Managing relationships with primary stakeholders helps firms develop productive intangible assets, and thus create shareholder value (Hillman and Keim 2001). Secondary stakeholders do not get directly involved in direct transactions with the firms (Jamali 2008). We thereby classified CSR activities according to their target stakeholder groups (Buysse and Verbeke 2003). The items for concerns for primary stakeholders (Concerns_primary stakeholders) are from the KLD categories including employee relations, diversity dimensions, and product relations. The items for concerns for secondary stakeholders (Concerns_secondary stakeholder) are from KLD categories including community relations, and environmental and human rights.

In columns 1-3 of Table 7, we separately examine stakeholder conflicts, concerns for primary stakeholders, and concerns for secondary stakeholders. We documented a significant and positive coefficient on stakeholder conflict in column 1. It appears that concerns for primary stakeholders have a significant and positive effect on bond yield spread at issuance under Rule 144A. However, the concerns for secondary stakeholders seem to have an insignificant effect on bond yield spread. Overall, the findings reported in Table 7 indicate that firms CSR strategies are not necessarily in line with the expectation of all of the stakeholder groups. Conflicts among various stakeholders may reflect the inefficient utilization of firm resources, which are more important for those firms that issue bonds under Rule 144A. More important, the stakeholder conflicts expose firms to higher risks, and consequently, investors demand higher bond yield spreads. Our results also reveal that the concerns for primary stakeholders are important. After all, primary stakeholders have a more salient footprint on a firm's business operation. 
Table 7. Exploring sources of risk exposure in CSR profiles and bond yield spread.

\begin{tabular}{|c|c|c|c|}
\hline \multirow{2}{*}{ Independent Variables } & \multicolumn{3}{|c|}{ Dependent Variable: Yield Spread (in logs) } \\
\hline & (1) & $(2)$ & (3) \\
\hline Stakeholder conflict & $\begin{array}{c}0.049 * * \\
(0.022)\end{array}$ & & \\
\hline Concerns_primary stakeholders & & $\begin{array}{c}0.038^{* *} \\
(0.016)\end{array}$ & \\
\hline Concerns_secondary stakeholders & & & $\begin{array}{c}0.024 \\
(0.028)\end{array}$ \\
\hline Firm size & $\begin{array}{c}-0.177^{* * * *} \\
(0.024)\end{array}$ & $\begin{array}{c}-0.166^{* * *} \\
(0.023)\end{array}$ & $\begin{array}{c}-0.159 * * * \\
(0.025)\end{array}$ \\
\hline Tobin's Q & $\begin{array}{c}-0.129 * * * \\
(0.039)\end{array}$ & $\begin{array}{c}-0.131^{* * *} \\
(0.039)\end{array}$ & $\begin{array}{c}-0.132 \text { *** } \\
(0.039)\end{array}$ \\
\hline Profitability & $\begin{array}{c}-1.327^{* * * *} \\
(0.365)\end{array}$ & $\begin{array}{c}-1.298^{* * *} \\
(0.372)\end{array}$ & $\begin{array}{c}-1.353^{* * *} \\
(0.373)\end{array}$ \\
\hline Sales growth rate & $\begin{array}{c}-0.002^{* * *} \\
(0.001)\end{array}$ & $\begin{array}{c}-0.002 \text { *** } \\
(0.001)\end{array}$ & $\begin{array}{c}-0.002 * * * \\
(0.001)\end{array}$ \\
\hline Book leverage & $\begin{array}{c}0.984^{* * *} \\
(0.143)\end{array}$ & $\begin{array}{c}0.983^{* * *} \\
(0.143)\end{array}$ & $\begin{array}{c}0.985^{* * *} \\
(0.145)\end{array}$ \\
\hline Maturity & $\begin{array}{c}0.004 \\
(0.004)\end{array}$ & $\begin{array}{c}0.003 \\
(0.004)\end{array}$ & $\begin{array}{c}0.003 \\
(0.004)\end{array}$ \\
\hline Issue size & $\begin{array}{c}-0.000 * * \\
(0.000)\end{array}$ & $\begin{array}{c}-0.000 * * \\
(0.000)\end{array}$ & $\begin{array}{c}-0.000 * * \\
(0.000)\end{array}$ \\
\hline Debt rating & $\begin{array}{c}-0.461^{* * *} \\
(0.091)\end{array}$ & $\begin{array}{c}-0.455^{* * *} \\
(0.091)\end{array}$ & $\begin{array}{c}-0.445^{* * *} \\
(0.090)\end{array}$ \\
\hline Constant & $\begin{array}{c}7.280^{* * * *} \\
(0.221)\end{array}$ & $\begin{array}{c}7.183^{* * *} \\
(0.220)\end{array}$ & $\begin{array}{c}7.139 * * * \\
(0.226)\end{array}$ \\
\hline Year fixed effect & Yes & Yes & Yes \\
\hline Firm fixed effect & Yes & Yes & Yes \\
\hline Observations & 892 & 892 & 892 \\
\hline Adjusted R-squared & 0.709 & 0.708 & 0.705 \\
\hline
\end{tabular}

$* * * \overline{p<0.01, * *} p<0.05, * p<0.1$. This table reports the regression results relating various aspects of CSR profiles to bond yield spread at issuance under Rule 144A. The dependent variable is the natural logarithm of yield spread at issuance. Stakeholder conflicts capture the complexity in CSR strategy and stakeholder risk. Concerns_primary stakeholder is the CSR_concerns related to primary stakeholders, including employee relations, diversity, and product relations. Concerns_secondary stakeholder is the CSR_concerns related to secondary stakeholders, including the community, and environmental and human rights. We use the state voting records in presidential elections as the instrument variable of the firm's CSR involvement. Firm size is measured as the natural logarithm of book assets. Tobin's $Q$ is measured as firm market capitalization divided by the book value of firm assets. Profitability is measured as firm return on assets. Sales growth rate is measured as the percentage change of firm net sales from year $t-1$ to year $t$. Book leverage is the ratio of total debt over the book value of firm assets. Maturity is the number of years from bond issuance to maturity. Debt rating is the S\&P long-term debt rating, with a rating of 22 for grade AAA and one for grade D. Issuing size is the bond proceeds. Clustered standard errors by issuers are reported in parentheses.

\section{Summary and Conclusions}

This study investigates the relationship between CSR and the firm cost of capital from the debt-holder perspective. Particularly, we focus on bonds issued under Rule 144A, because the issuing firms tend to have lower credit quality, and the investors are qualified and sophisticated institutional investors. Rule 144A bond issuances provide an ideal setting to investigate how institutional investors make use of the information in the CSR profiles of issuing firms. Moreover, given that issuing firms 
may have limited organizational slack and limited access to the public debt market, we may gain new insights regarding the effects of investments in CSR activities on firm financial outcomes.

Our empirical analyses reveal that the CSR concerns of issuing firms result in a higher bond yield spread at issuance. However, we only document an insignificant effect of CSR strengths on bond pricing. It is plausible that the benefits of engaging in CSR activities do not justify the cost of diverting productive resources to achieve socially desirable outcomes, at least for the issuing firms in our sample. Nevertheless, CSR concerns may expose issuing firms to higher risk (e.g., litigation risk) and have an adverse effect on the ability of issuing firms to repay the debt. Consequently, investors of Rule 144A bonds demand higher premiums for firms with higher CSR concerns. Additionally, institutional investors purchasing Rule 144A bonds indeed extract information from both cross-sectional and time-series variations in issuing firms' CSR profiles. Our empirical results indicate that the main sources of risk exposure due to externalities of CSR activities are stakeholder conflicts and concerns from primary stakeholders.

Our research has important managerial implications for practitioners as well. CSR strategies are not isolated decisions, and their instrumental value can only be evaluated in conjunction with other critical firm decisions. Since the effectiveness of CSR strategies is context-dependent, resource configuration and allocation to CSR activities has to be integrated with firm core business and operation. Moreover, corporate managers need to take into consideration the externalities of socially irresponsible activities, because those activities may expose the firms to significant risk and reduce firm value.

Nonetheless, our study is not without limitations. For example, because of the lack of information on the qualified institutional investors, we do not know who purchases the bonds issued under Rule 144A. Therefore, we are unable to further explore the dynamics regarding the interactions between the bond issuers and bond buyers, which hinders our understanding of the underlying mechanisms in the issuing process of Rule 144A debt offerings. Furthermore, we do not explicitly examine those issuers with experience related to both public issuances and private placements. It appears that the effects of CSR vary in different contexts, and not every economic agent interprets the information regarding CSR in the same way. These limitations also present future research opportunities to advance our understanding regarding the role played by corporate social responsibility in the capital markets.

Author Contributions: J.W. performed the empirical analysis. W.D. contributed to idea generation and improved the empirical analysis. D.J. and H.W. contributed to the conceptualization of this paper and drafted the manuscript.

Funding: This research is supported by the National Social Science Foundation (Grant 13CTJ003), and China Postdoctoral Science Foundation (Grant 2014M562025).

Conflicts of Interest: The authors declare no conflict of interest.

\section{References}

Albring, Susan M., Inder K. Khurana, Ali Nejadmalayeri, and Raynolde Pereira. 2011. Managerial compensation and the debt placement decision. Journal of Corporate Finance 17: 1445-56. [CrossRef]

Albuquerque, Rui A., Art Durnev, and Yrjo Koskinen. 2014. Corporate Social Responsibility and Firm Risk: Theory and Empirical Evidence. London: CEPR.

Amiraslani, Hami, Karl Lins, Henri Servaes, and Ane Tamayo. 2018. The Bond Market Benefits of Corporate Social Capital. Working Paper. Brussels: European Corporate Governance Institute.

Amit, Raphael, and Birger Wernerfelt. 1990. Why do firms reduce business risk? Academy of Management Journal 33: 520-33. [CrossRef]

Arena, Matteo P. 2011. The corporate choice between public debt, bank loans, traditional private debt placements, and 144A debt issues. Review of Quantitative Finance and Accounting 36: 391-416. [CrossRef]

Bae, Kee-Hong, Jun-Koo Kang, and Jin Wang. 2011. Employee treatment and firm leverage: A test of the stakeholder theory of capital structure. Journal of Financial Economics 100: 130-53. [CrossRef]

Barnea, A., and Amir Rubin. 2005. Corporate Social Responsibility as a Conflict between Owners. Working Paper. Burnaby: Simon Fraser University. 
Barnett, Michael L., and Robert M. Salomon. 2006. Beyond dichotomy: The curvilinear relationship between social responsibility and financial performance. Strategic Management Journal 27: 1101-22. [CrossRef]

Becchetti, Leonardo, Rocco Ciciretti, Iftekhar Hasan, and Nada Kobeissi. 2012. Corporate social responsibility and shareholder's value. Journal of Business Research 65: 1628-35. [CrossRef]

Becchetti, Leonardo, Rocco Ciciretti, and Alessandro Giovannelli. 2013. Corporate social responsibility and earnings forecasting unbiasedness. Journal of Banking $\mathcal{E}$ Finance 37: 3654-68. [CrossRef]

Becchetti, Leonardo, Rocco Ciciretti, and Iftekhar Hasan. 2015. Corporate social responsibility, stakeholder risk, and idiosyncratic volatility. Journal of Corporate Finance 35: 297-309. [CrossRef]

Benlemlih, Mohammed, and Isabelle Girerd-Potin. 2017. Corporate social responsibility and firm financial risk reduction: On the moderating role of the legal environment. Journal of Business Finance E Accounting 44: 1137-66.

Bettis, Richard A. 1983. Modern financial theory, corporate strategy and public policy: Three conundrums. Academy of Management Review 8: 406-15. [CrossRef]

Bharath, Sreedhar T., Sandeep Dahiya, Anthony Saunders, and Anand Srinivasan. 2011. Lending Relationships and Loan Contract Terms. Review of Financial Studies 24: 1141-203. [CrossRef]

Brammer, Stephen, and Andrew Millington. 2008. Does it pay to be different? An analysis of the relationship between corporate social and financial performance. Strategic Management Journal 29: 1325-43. [CrossRef]

Buysse, Kristel, and Alain Verbeke. 2003. Proactive environmental strategies: A stakeholder management perspective. Strategic Management Journal 24: 453-70. [CrossRef]

Cai, Li, Jinhua Cui, and Hoje Jo. 2016. Corporate environmental responsibility and firm risk. Journal of Business Ethics 139: 563-94. [CrossRef]

Chan, MuiChing Carina, John Watson, and David Woodliff. 2014. Corporate governance quality and CSR disclosures. Journal of Business Ethics 125: 59-73. [CrossRef]

Chandra, Uday, and Nandkumar Nandu Nayar. 2008. The information content of private debt placements. Journal of Business Finance \& Accounting 35: 1164-95.

Chang, Kiyoung, Incheol Kim, and Ying Li. 2014. The heterogeneous impact of corporate social responsibility activities that target different stakeholders. Journal of Business Ethics 125: 211-34. [CrossRef]

Chaplinsky, Susan, and Latha Ramchand. 2004. The impact of SEC rule 144A on corporate debt issuance by international firms. The Journal of Business 77: 1073-98. [CrossRef]

Chava, Sudheer. 2014. Environmental Externalities and Cost of Capital. Management Science 60: 2223-47. [CrossRef]

Cheng, Beiting, Ioannis Ioannou, and George Serafeim. 2014. Corporate social responsibility and access to finance. Strategic Management Journal 35: 1-23. [CrossRef]

Cheung, Adrian Wai Kong. 2016. Corporate social responsibility and corporate cash holdings. Journal of Corporate Finance 37: 412-30. [CrossRef]

Chou, Robin, and Miaw-Jane Chen. 2014. Long-Run Stock Return and Operating Performance Following Private Debt Placements. NTU Management Review 25: 33-62. [CrossRef]

Dang, Chongyu, Zhichuan Li, and Chen YangYang. 2018. Measruing firm size in empirical corporate finance. Journal of Banking and Finance 86: 159-76. [CrossRef]

Degryse, Hans, and Steven Ongena. 2001. Bank Relationships and Firm Profitability. Financial Management 30: 9-34. [CrossRef]

Deng, Xin, Jun-koo Kang, and Buen Sin Low. 2013. Corporate social responsibility and stakeholder value maximization: Evidence from mergers. Journal of Financial Economics 110: 87-109. [CrossRef]

Denis, David J., and Vassil T. Mihov. 2003. The choice among bank debt, non-bank private debt, and public debt: Evidence from new corporate borrowings. Journal of Financial Economics 70: 3-28. [CrossRef]

Dennis, Steven, Debarshi Nandy, and Lan G. Sharpe. 2000. The determinants of contract terms in bank revolving credit agreements. Journal of Financial and Quantitative Analysis 35: 87-110. [CrossRef]

Di Giuli, Alberta, and Leonard Kostovetsky. 2014. Are red or blue companies more likely to go green? Politics and corporate social responsibility. Journal of Financial Economics 111: 158-80. [CrossRef]

El Ghoul, Sadok, Omrane Guedhami, Chuck C. Y. Kwok, and Dev R. Mishra. 2011. Does corporate social responsibility affect the cost of capital? Journal of Banking $\mathcal{E}$ Finance 35: 2388-406. [CrossRef]

Fenn, George W. 2000. Speed of issuance and the adequacy of disclosure in the 144A high-yield debt market. Journal of Financial Economics 56: 383-405. [CrossRef] 
Francis, Bill, Iftekhar Hasan, Liuling Liu, and Haizhi Wang. 2018. Employee Treatment and Contracting with Bank Lenders: An Instrumental Approach for Stakeholder Management. Journal of Business Ethics. in press. [CrossRef]

Garriga, Elisabet, and Domènec Melé. 2004. Corporate social responsibility theories: Mapping the territory. Journal of Business Ethics 53: 51-71. [CrossRef]

Godfrey, Paul C. 2005. The relationship between corporate philanthropy and shareholder wealth: A risk management perspective. Academy of Management Review 30: 777-98. [CrossRef]

Godfrey, Paul C., Craig B. Merrill, and Jared M. Hansen. 2009. The relationship between corporate social responsibility and shareholder value: An empirical test of the risk management hypothesis. Strategic Management Journal 30: 425-45. [CrossRef]

Goss, Allen, and Gordon S. Roberts. 2011. The impact of corporate social responsibility on the cost of bank loans. Journal of Banking $\mathcal{E}$ Finance 35: 1794-810. [CrossRef]

Greg, Filbeck, Raymond Gorman, and Xin Zhao. 2009. Best corporate citizens good for shareholders. The Financial Review 44: 239-62.

Harjoto, Maretno A., and Hoje Jo. 2015. Legal vs. normative CSR: Differential impact on analyst dispersion, stock return volatility, cost of capital, and firm value. Journal of Business Ethics 128: 1-20. [CrossRef]

Harjoto, Maretno, and Indrarini Laksmana. 2016. The Impact of Corporate Social Responsibility on Risk Taking and Firm Value. Journal of Business Ethics 151: 353-73. [CrossRef]

Harris, Milton, and Artur Raviv. 1996. The capital budgeting process: Incentives and information. The Journal of Finance 51: 1139-74. [CrossRef]

Harrison, Jeffrey S., and Douglas A. Bosse. 2013. How much is too much? The limits to generous treatment of stakeholders. Business Horizons 56: 313-22. [CrossRef]

Harrison, Jeffrey S., Douglas A. Bosse, and Robert A. Phillips. 2010. Managing for stakeholders, stakeholder utility functions, and competitive advantage. Strategic Management Journal 31: 58-74. [CrossRef]

Hasan, Iftekhar, Nada Kobeissi, Liuling Liu, and Haizhi Wang. 2018. Corporate Social Responsibility and Firm Financial Performance: The Mediating Role of Productivity. Journal of Business Ethics 149: 671-88. [CrossRef]

Hillman, Amy J., and Gerald D. Keim. 2001. Shareholder value, stakeholder management, and social issues: What's the bottom line? Strategic Management Journal 22: 125-39. [CrossRef]

Hirshleifer, Jack. 1961. Risk, the discount rate, and investment decisions. American Economic Review 61: 112-20.

Hsu, Feng Jui, and Yu-Cheng Chen. 2015. Is a firm's financial risk associated with corporate social responsibility? Management Decision 53: 2175-99. [CrossRef]

Huang, Rongbing, and Gabriel G. Ramirez. 2010. Speed of issuance, lender specialization, and the rise of the 144A debt market. Financial Management 39: 643-73. [CrossRef]

Jamali, Dima. 2008. A stakeholder approach to corporate social responsibility: A fresh perspective into theory and practice. Journal of Business Ethics 82: 213-31. [CrossRef]

Jiraporn, Pornsit, Napatsorn Jiraporn, Adisak Boeprasert, and Kiyoung Chang. 2014. Does corporate social responsibility (CSR) improve credit ratings? Evidence from geographic identification. Financial Management 43: 505-31. [CrossRef]

Jo, Hoje, and Haejung Na. 2012. Does CSR reduce firm risk? Evidence from controversial industry sectors. Journal of Business Ethics 110: 441-56. [CrossRef]

Kleibergen, Frank, and Richard Paap. 2006. Generalized reduced rank tests using the singular value decomposition. Journal of Econometrics 133: 97-126. [CrossRef]

Kytle, Beth, and John Gerard Ruggie. 2005. Corporate social responsibility as risk management: A model for multinationals. Corporate Social Responsibility Initiative Working Paper No. 10. Cambridge: John F. Kennedy School of Government, Harvard University.

Lee, Darren D., and Robert W. Faff. 2009. Corporate sustainability performance and idiosyncratic risk. The Financial Review 44: 213-37. [CrossRef]

Li, Frank, Tao Li, and Dylan Minor. 2016. CEO power, corporate social responsibility, and firm value: A test of agency theory. International Journal of Managerial Finance 12: 611-28. [CrossRef]

Lins, Karl, Henri Servaes, and Ane Tamayo. 2017. Social capital, trust, and firm performance: The value of corporate social responsibility during the financial crisis. The Journal of Finance 72: 1785-824. [CrossRef]

Livingston, Miles, and Lei Zhou. 2002. The impact of Rule 144A debt offerings upon bond yields and underwriter fees. Financial Management 31: 5-27. [CrossRef] 
Luo, Xueming, and Chitra Bhanu Bhattacharya. 2009. The debate over doing good: Corporate social performance, strategic marketing levers, and firm-idiosyncratic risk. Journal of Marketing 73: 198-213. [CrossRef]

Mackey, Alison, Tyson B. Mackey, and Jay B. Barney. 2007. Corporate social responsibility and firm performance: Investor preferences and corporate strategies. Academy of Management Review 32: 817-35. [CrossRef]

Margolis, Joshua, and James Walsh. 2003. Misery loves companies: Rethinking social initatives by business. Administrative Science Quarterly 48: 268-305. [CrossRef]

McWilliams, Abagail, and Donald Siegel. 2001. Corporate social responsibility: A theory of the firm perspective. Academy of Management Review 26: 117-27. [CrossRef]

Minor, Dylan, and John Morgan. 2011. CSR as reputation insurance: Primum non nocere. California Management Review 53: 40-59. [CrossRef]

Oikonomou, Ioannis, Chris Brooks, and Stephen Pavelin. 2014. The effects of corporate social performance on the cost of corporate debt and credit ratings. Financial Review 49: 49-75. [CrossRef]

Orlitzky, Marc, and John D. Benjamin. 2001. Corporate social performance and firm risk: A meta-analytic review. Business E Society 40: 369-96.

Petersen, Mitchell A. 2009. Estimating Standard Errors in Finance Panel Data Sets: Comparing Approaches. Review of Financial Studies 22: 435-80. [CrossRef]

Peterson, Dane K. 2004. The relationship between perceptions of corporate citizenship and organizational commitment. Business \& Society 43: 296-319.

Ross, Stephen. 1978. A simple approach to the valuation of risky assets. Journal of Business 51: 453-75. [CrossRef]

Rubin, Amir. 2008. Political views and corporate decision making: The case of corporate social responsibility. Financial Review 43: 337-60. [CrossRef]

Salama, Aly, Keith Anderson, and J. S. Toms. 2011. Does community and environmental responsibility affect firm risk? Evidence from UK panel data 1994-2006. Business Ethics: A European Review 20: 192-204. [CrossRef]

Stulz, René M. 1996. Rethinking risk management. Journal of Applied Corporate Finance 9: 8-25. [CrossRef]

Surroca, Jordi, Josep A Tribó, and Sandra Waddock. 2010. Corporate responsibility and financial performance: The role of intangible resources. Strategic Management Journal 31: 463-90. [CrossRef]

Waddock, Sandra, and Samuel Graves. 1997. The corporate social performance-financial performance link. Strategic Management Journal 18: 303-19. [CrossRef]

(C) 2018 by the authors. Licensee MDPI, Basel, Switzerland. This article is an open access article distributed under the terms and conditions of the Creative Commons Attribution (CC BY) license (http:/ / creativecommons.org/licenses/by/4.0/). 